\title{
Improving the Legitimacy of Investor - State Dispute Settlement System: Can the WTO DSU System Act as a Model?
}

\author{
Dr. Julius Cosmas ${ }^{1}$ \\ ${ }^{1}$ Faculty of Law, Mzumbe University, Morogoro, Tanzania \\ Correspondence: Dr. Julius Cosmas, Mzumbe University, Faculty of Law, P O Box 9 - Mzumbe, Morogoro, \\ Tanzania. E-mail: swigo2003@gmail.com
}

Received: November 18, 2014 Accepted: December 6, 2014 Online Published: April 4, 2015

doi:10.5539/ilr.v4n1p1

URL: http://dx.doi.org/10.5539/ilr.v4n1p1

\begin{abstract}
While the World Trade Organisation dispute settlement system is prospering, the investor - state dispute settlement system is in shambles and need immediate attention. This article argues that investor - state dispute settlement system need to gather experience from the WTO system so as to increase its legitimacy. The article looks at the issues haunting the investor - state adjudication system and examines how the same have been addressed at the World Trade Organisation. The WTO DSU is taken as a comparator because it is being praised for attaining legitimacy within a short period of time. The article concludes that investor - state adjudicative system has a lot to learn from the WTO adjudicative system with regards to costs, timeframe, remedies and the appellate structure.
\end{abstract}

Keywords: investor - state adjudication system, legitimacy crisis, WTO dispute settlement system, WTO success, addressing legitimacy issues in investor - state system

\section{Introduction}

It is clear that investor - state dispute settlement system is undergoing a legitimacy crisis. 'Legitimacy' is defined as the basis upon which people accept or are willing to accept the legal order as they find it and is premised upon the idea that law should be good for, and justly serve, the people(Hurst,1971, p.225; Horse, 2000, p.218). Stakeholders have shown their dissatisfaction either by denouncing the system or by amending their BITs to exclude investor - state arbitration system. These adverse steps signal that all is not well and calls for immediate attention. This article looks at the issues haunting the investor - state adjudication system and examines how the same have been addressed at the World Trade Organisation. The WTO DSU is taken as a comparator because it is being praised for attaining legitimacy within a short period of time. The Article is divided in six parts. The first part identifies the legitimacy issues in the investor - state adjudication system. The part concludes that indeed the issues are many and need an immediate address. The second part identifies the stakeholders' reactions and measures they have taken against the investor - state system. The third part discusses the WTO DSU system and concludes that the WTO has indeed managed to garner world support within a short period of time. The fourth part makes a comparative analysis between the WTO and investor - state adjudication systems. The main issues which make the WTO a success and the investor - state a failure are analysed in this section. The fifth part discusses possible obstacles to the improvements of the investor - state system. The section submits that despite these obstacles the adoption of WTO approach could serve the system from the imminent danger of collapsing. The last and fifth part is a conclusion which concludes that investor - state system need to learn from the WTO system on how to address its major systemic issues.

\section{Legitimacy Issues}

A number of issues are responsible for the crisis. Under the current system there is no mechanism in place to avoid inconsistent decisions (SGS Société Générale de Surveillance S A v Islamic Republic of Pakistan, 2003 and SGS Société Générale de Surveillance S A v Republic of the Philippines,2004), there are no adequate rules to ensure an impartial and independent adjudication process, there are no rules to ensure transparency despite the fact that the disputes are public in nature, and there is no appellate system to rectify errors (Van Harten et al, 2010, Mann, 2011, p.22; Reinisch, 2009, p.894 ). In addition, these uncoordinated and unsupervised tribunals at times encroach on governments' regulatory powers by rendering awards which challenge or illegalise legitimate laws passed by states. Recently the international community has witnessed a number of cases challenging the 
host state's basic regulatory functions and sometimes the state's duty to provide public services to its citizens (Aguas del Tunari S A v Bolivia, 2005, and Azurix Corp v Argentina, 2006). In some cases the main function of the state, viz, security and peace is put in jeopardy but still the standard of review applied by the tribunals does not take these factors into consideration (CMS Gas Transmission Company v The Argentine Republic, 2005, and Enron Corporation and Ponderosa Assets L P $\mathrm{v}$ Argentine Republic, 2007). Furthermore, state regulatory measures on environmental issues, health and other service delivery to the citizens have been declared illegal in favour of foreign investors' interests (Philip Morris Asia Limited v. The Commonwealth of Australia, 2012, and Vattenfall v Federal Republic of Germany, 2013).

\section{Stakeholders Reactions}

In reaction to the abovementioned flaws in the system, some stakeholders have started running away from the investor - state arbitration system. Latin America countries, viz, Bolivia, Ecuador, and Venezuela, have led the way by withdrawing from the ICSID Convention (United Nations Conference on Trade and Development (UNCTAD), 2012, p. 84).

Australia, on the other hand, in an effort to seek more policy space in April 2011 issued a trade policy statement announcing that it would stop including investor - state dispute settlement clauses in its future International Investment Agreements (IIAs) (Department of Foreign Affairs and Trade of Australia, 2011). However, it should be noted that with the change of government in 2013, the new Australia- Korea FTA which includes an investment chapter has incorporated investor-state arbitration (Lester, 2014). With the aim of addressing the host state policy making space, the new FTA comes with the 'general exception' to investment obligations which parallel WTO exception provisions such as GATT Article XX and GATS Article XIV (Lester, 2014).

The United States has also revised its model Bilateral Investment Treaty (BIT) in order to constrain the expansive interpretations by tribunals. The revised model BIT empowers the US government more to regulate on different issues, viz, health, safety, environment, and the promotion of internationally recognized labour rights without interference from the investor - state tribunals (The Office of the United States Trade Representative, US Model Bilateral Investment Treaty (2012), Art.12). In addition to that, the US 2012 model BIT mandates the Parties to 'consider' whether arbitral awards under the BIT should be subject to any new appellate mechanism to be introduced in the future (The Office of the United States Trade Representative, US Model Bilateral Investment Treaty (2012), Art. 28(10).

South Africa has also shown its dissatisfaction with the current dispute settlement system (The Department of Trade and Industry,(DTI) 2009). The government in 2009 issued a policy statement with regard to BITs. In an effort to balance interests between host state and foreign investors, the government has denounced a number of BITs with European countries and is pushing for utilisation of host state courts in the event of any disputes between South Africa and foreign investors (DTI, 2012). In another move, the South African government in November 2013 published its draft Promotion and Protection of Investment Bill 2013 in the Government Gazette for public comment (South Africa Draft Bill on Promotion and Protection of Investment, 2013). The bill provides for domestic litigation, domestic arbitration and mediation of investment disputes ((South Africa Draft Bill on Promotion and Protection of Investment, 2013), Art.11).

In March 2014, Germany also announced its dissatisfaction with the investor - state arbitration system and is opposing the inclusion of the system in the EU - US trade pact which is currently under negotiation (Investment Treaty News, 2014, p.16). Germany is taking the same stance on the recently concluded Comprehensive Economic and Trade Agreement (CETA) between EU and Canada (EU - Canada Comprehensive Economic and Trade Agreement (CETA), 2014). Germany is advancing the idea of adjudicating investor - state disputes in the host state courts. According to the Financial Times, the Junior Minister of Economy, Brigitte Zypries, believes that foreign investors 'have sufficient legal protection in the national courts' (Financial Times, May 2014, p.16).

Apart from countries, other stakeholders have also shown concern about the current dispute settlement mechanism. The Committee on International Trade of the European Parliament, on 22 March 2011 issued a Report on the future of International Investment Policy of the European Union (European Union Parliament Report on the Future European International Investment Policy, (EU Parliament), 2011). The Report highlighted the problem relating to: different interpretations of investment principles by different tribunals which lead to conflict between private interests and the regulatory tasks of public authorities (EU Parliament,2011, para G); the existence of BITs which focus on the interests of investors alone and disregard the host state interests in regulating for other development goals (EU Parliament,2011, para $J(1)$ ); and the lack of a model BIT for member states which can enhance certainty and consistency of interpretation (EU Parliament,2011, para J(4)). In addition, the Report raises concerns about the wide discretionary powers granted to arbitrators on 
interpretation of the investment principles (EU Parliament, 2011, para 17). The Report raises further concerns about the lack of transparency in the current system, the lack of an appellate option and the absence of the requirement for exhaustion of local remedies before resorting to international arbitration (EU Parliament,2011, para 31).

Furthermore, the Law professors from different parts of the world in 2010 issued a public statement condemning the current investment arbitration system (Van Harten, 2010 p. 1 - 8). Among the concerns raised in the public statement are: the need to have an independent judicial system responsible for investment disputes; recognition of the state's fundamental right to regulate on behalf of public welfare; the need for arbitrators to consider the public interest in their interpretation of investment principles; and that the current adjudication system is not a fair, independent and balanced system for settlement of investment disputes (Van Harten, 2010 p. 1 - 8).

From the stakeholders' reactions noted above, it is submitted here that it is evident that the system is experiencing a legitimacy crisis. On the other hand, the WTO DSU is enjoying full support from all angles of the world.

\section{World Trade Organisation System}

It is almost twenty years now since the WTO came into being. As earlier said, the system has achieved a lot and is commended for ensuring 'the prompt settlement of disputes between WTO Members concerning their rights and obligations under the covered agreements and achieving predictability of the dispute settlement system and satisfactory settlement of disputes (Bosche, 2005, p. 172). To be specific, the WTO is hailed for, first of all, setting up a strict timeframe within which a dispute has to be resolved. Secondly, the WTO is hailed for establishing an Appellate Structure which hears Appeals emanating from the panel decisions. Lastly, the WTO is hailed for setting up a mechanism of ensuring that the implementation of the adjudicatory body decision is done within the time stipulated by the DSU (Zimmermann, 2005, p.27). All these improvements were made to address the deficiencies found in the former GATT 1947 dispute settlement system (Davey, 1987, 58).

Different scholars have written on the DSU success. Bhala, for example, calls the WTO dispute settlement system as the "crown jewel" and a "core linchpin" of the multilateral trading system (Bhala, 1999, p.856). Hudec on the other hand has termed the WTO DSB as a legal tribunal which has been given 'unprecedented powers' by the trading nations (Hudec, 2004, p. 53; Mc Rae, 2004, p. 3 - 5). Sutherland in his Consultative Report for the Board of the WTO to mark 10 years of the DSB hails the Dispute Settlement Body as 'a unique system which fosters security and predictability'(The Future of the WTO, 2004). It can be concluded here that the success of WTO in resolving international trade dispute is unprecedented.

The WTO website indicates that by $26^{\text {th }}$ March 2014 a number of disputes filed at the WTO have reached 474 cases (WTO Website, 2014). It should be noted that 474 cases in 19 years signifies that the system is pretty active when compared to the less than 300 cases submitted to GATT dispute settlement in all 47 years of its existence (WTO Website, 2014).

\section{What to Learn from the WTO Counterpart}

The successful story of the WTO can indeed act as a model towards creating a legitimate investor - state adjudicative system. As discussed in the introduction above, exorbitant costs, lack of strict timeframe for settling disputes, excessive damages awards, encroachment on government policy making space and lack of appellate structure to be among the main problems affecting the legitimacy of investor - state adjudicative system. It is submitted here that the WTO system can be looked at in the efforts of addressing these issues. In the following part, a comparative analysis is made between the investor - state adjudicative system and the WTO system regarding these issues.

\subsection{Costs}

With regard to costs, under the current investor - state adjudicative system the cost for litigating in one case is too high. The UNCTAD World Investment Report 2010 clearly state that the costs in investor - state disputes have skyrocketed (UNCTAD, 2010, p 16 - 18). It is evident clear that arbitrators' charges range from USD 350 700 per hour per arbitrator depending on the claimed dispute amount (International Centre for Settlement of Investment Disputes -ICSID), 2014). The total amount per case therefore depends on the number of days the Tribunal have sat and the complexity of the matter. It is also not in dispute that the cost for one case ranges from 1 million to 21 million USD as most of the Tribunals are constituted by three arbitrators and several lawyers for both sides and take months before the dispute is put to rest (Franck, 2011, p.769; Eberhardt \& Olivert, p. 2012). These exorbitant costs at times intimidate poor developing countries from litigating hence decides to give in to the foreign investor demands even where doing so interferes with its other policy objectives (UN Special 
Representative of the Secretary General,2010, 20 - 23).

While disputes under investor - state adjudicative system is settled on account of millions of US dollars, at the WTO that is not the case. A study conducted in 2009 indicates that the cost of adjudicating a dispute at WTO involving a sequence of consultations and panel and appeal proceedings, are in the range of US\$500,000 (Nortage, 2009; Nordstroom \& Schaffer, 2014). The reason for WTO costs being lower than in investor - state arbitration can be attributed to a number of reasons which are discussed hereunder.

First of all, Under the WTO system, the issue of minimizing litigation costs is given high priority and is addressed through a number of ways. Firstly, as discussed under chapter five, the Advisory Centre on WTO Law has been established for the purposes of rendering legal assistance to developing countries. The WTO Centre provides legal aid to developing countries and least developed countries. The Centre is Co - owned by the developed in collaboration with the developing countries of the world but only provide legal assistance to least developing countries, developing countries and the economy in transition countries (WTO Advisory Centre, 2014). The Centre represent the respondent states at a discounted price but at times, the service is rendered for free if the respective respondent state fall in the least developed countries (WTO Advisory Centre, 2014). It is submitted here that through this kind of arrangements, legal costs impediment will diminish if the western world and TNCs agree to sponsor a legal aid centre for the purposes of creating a balanced investor - state adjudicative system.

Secondly, costs issue at WTO is addressed internally. As discussed earlier, at panel and appellate stage the parties to the dispute are exonerated from paying costs for the Appellate Body presiding members. Article 8(11) and 17 (8) of the DSU respectively provides that 'the expenses of persons serving on the panel and Appellate Body, including travel and subsistence allowance, shall be met from the WTO budget in accordance with criteria to be adopted by the General Council, based on recommendations of the Committee on Budget, Finance and Administration' (WTO Dispute Settlement Understanding, (DSU), 1995, Art. 8(11) and 17(8)). By footing the bill at both stages, the WTO is opening up to any party who is not satisfied with the panel report on the point of law to approach the highest body in hierarchy, the Appellate Body, for clarification. It is submitted here that while this move intends to make the adjudicative system accessible in terms of costs, it also helps in building a consistent jurisprudence on WTO agreements. The fact that the AB jurisdiction is confined to issues on the point of law, it follows therefore that the more appeals it decides the more solid jurisprudence is created on relevant agreements and provisions.

In addition to that, the WTO also recognizes the need to assist developing countries in terms of legal services. Article 27(2) of the DSU mandates the Secretariat to appoint an expert who can assist a developing country in a dispute. The article provides that the WTO Secretariat may make experts available to developing countries to provide 'legal advice and assistance in respect of dispute settlement'. This initiative from within the WTO shows that the system aims at to levelling the playing field, particularly for the economically and politically weakest countries. This means that the small countries can confront the big countries on an equal footing (Torres, $2012 \mathrm{p}$. 20).

In conclusion, it is submitted here that, the investor - state system can learn a lot from the WTO DSM on how to cut litigation costs so as to make it accessible to all stakeholders. As pointed out earlier, high litigation costs in the investor - state arbitration affect the legitimacy of the system to a large extent.

\subsection{Dispute Settlement Timeframe}

Another area where the investor - state adjudicative system can benefit from the WTO is on dispute settlement timeframe. A recent study indicates that at ICSID a dispute takes up to an average of $4-5$ years (Raviv, 2014, p.4). In fact there are cases which have been dragging at ICSID for over 11 years. Antoine Goetz v. Burundi (ICSID Case No ARB/01/2.), for example, was filed in December 2000 and ended in June 2012 (ICSID List of Cases, 2012), (over 11 years); EDF International S.A. v. Argentina (ICSID Case No ARB/03/23) was filed in June 2003 and ended in June 2012 (over 9 years), just to mention a few.

On the other hand, The WTO DSU clearly provides for the timeframe within which the dispute is supposed to be resolved. As discussed hereinabove, Article 20 of the DSU clearly set out the timeframe of settling WTO disputes to nine months where no appeal lie to the $\mathrm{AB}$ and 12 months where there was an appeal. This means that the dispute at Panel level takes nine months while at AB it takes three months. The WTO timeframe is not too rigid as the Panel and the $\mathrm{AB}$ are in complex cases allowed to take some more time as long as the delay will not take more than 9 months and the DSB in writing of the reason for the delay, (DSU), 1995, Art. 12(9) \& 17 (5)). Through this timeframe the WTO DSU has managed to achieve its main objective which is "prompt settlement of disputes between WTO Members concerning their rights and obligations under the covered 
agreements and achieving predictability of the dispute settlement system and satisfactory settlement of disputes' (WTO DSU Art. 3(2) \& 3(7)).

\subsection{Focused on Rectification of a Measure instead of Damages}

The investor - state adjudicative system is more focused on awarding punitive damages against the respondent state and not on requiring the respondent state to rectify the inconsistent measure. Stakeholders have voiced concerns that focusing on damages motivates foreign investors to institutes at times frivolous and vexatious claims (Jagusch \& Sullivan, 2010,P.79- 110). In CME v Czech Republic, the Tribunal issued a substantial total damages award in favour of CME of USD 354,655,752 USD (CME Czech Republic BV v The Czech Republic ICSID Reports, 2003, para 615). It further revealed that Argentina is currently faced with awards which run over USD 430 million and pending claims to the tune of 65 billion USD. In another case, Hulley Enterprises Limited (Cyprus) $v$ The Russian Federation, the amount claimed against Russia by the three majority shareholders of the former Yukos Oil Company in the ongoing arbitration proceedings against Russia is USD 114 billion (PCA Case No AA 228.). One can see that dispute resolution in investor - state arbitration has turned out to be a goldmine in which the foreign investor if successfully sued can earn a lot of profit from. The awards at times include the estimated loss of profit to the foreign investor for future twenty years (Newcombe \& Paradell, 2009,p. 377; Sornarajah, 2004, p. 435).

To the contrary, the WTO DSU is much focused on ensuring that the concerned member at fault brings the measure into conformity with the respective WTO Agreement. Article 19(1) of the DSU provides as follows (WTO DSU, 1995, Art.19 (1)):

'Where a panel or the Appellate Body concludes that a measure is inconsistent with a covered agreement, it shall recommend that the Member concerned9 bring the measure into conformity with that agreement.10 In addition to its recommendations, the panel or Appellate Body may suggest ways in which the Member concerned could implement the recommendations'.

Within 30 days after the adoption of the Panel or $\mathrm{AB}$ decision, the respective member is required to inform the DSB about its plan on how it intend to implement the decision (WTO DSU,1995, Art. 21(3)). Unlike Investor state adjudicative system, compensation and the suspension of concessions or other obligations are temporary measures available as a second remedy where the defaulting member state fails to bring the measure in consistency with the WTO Agreement. At WTO neither compensation nor the suspension of concessions or other obligations is preferred to full implementation of a recommendation to bring a measure into conformity with the covered agreements (WTO DSU, 1995, Art.22(1)).

Therefore in conclusion, it is submitted here that the WTO focus on bringing the measure in consistency furthers the aim of the DSU which is to create a predictable dispute resolution system. The investor - state adjudicative system focus on punitive damages creates unnecessary legitimacy crisis in international investment law. It is the view of this research that change of focus should be undertaken in which the Tribunals should at first try to advise the state to bring the measure in consistency with the BIT. Failure of which, the Tribunal should then focus on awarding damages against a non - willing host state.

\subsection{Uniform Standard of Review}

Investor - state arbitration system lacks a uniform and acceptable standard of review to be accorded to government measures. BITs do not provide any guidance to the arbitral Tribunals on the standard of review to be adopted in case of conflict between foreign investor's interests and the host state sovereign powers to regulate in its territory (Vadi \& Gruszczynski, 2013, p 615). Some Tribunals accord the deference to host states while others do not (Schill, 2012). As a result, inconsistency of awards occurs despite the fact that Tribunals are evaluating the scope and validity of the same government measure (CMS Gas Transmission Company $v$ The Argentine Republic; $L G \& E$ Energy Corp LG\&E Capital Corp and LG\&E International Inc v Argentine Republic).

However at the WTO this is not the case. Article 11 of the DSU requires the Panel to apply a uniform objective standard of review of all matters before it (WTO DSU, 1995, Art. 11). In EC Measures Concerning Meat and Meat Products (Hormones) (EC Measures Concerning Meat and Meat Products, 1998 para 116), the AB held that 'Article 11 articulates with great succinctness but with sufficient clarity the appropriate standard of review for panels in respect of the ascertainment of facts'. The Appellate Body further stressed that 'the standard of review must reflect the balance established in [WTO law] between the jurisdictional competences conceded by the Members to the WTO and the jurisdictional competences retained by the Members for themselves' ((EC Measures Concerning Meat and Meat Products, 1998 para, 115).

Having a uniform standard of review which allows state parties some deference creates a harmonious 
relationship between the WTO systems with its member states. The Panels have a guidance on the scope they can scrutinize government measures. As a result, consistence is achieved in the WTO adjudicative system.

Therefore, the investor - state system can learn from the WTO on how to allow deference to genuine public interest government measures. As a result, consistency will prevail in the system and the legitimacy will be increased. To achieve this however, as earlier stated, there is a need to have a multilateral treaty which provide specifically for the standard of review in investor - state arbitration.

\subsection{Appellate Structure}

Lastly, the investor - state adjudicative system can gather experience from the WTO on the form and the working modality of the Appellate Structure. Creating an appellate structure in the investor - state arbitration system is one of the proposal which have received overwhelming support from different stakeholders. However stakeholders have different proposals with regards to the modalities of forming the appellate structure. Some stakeholders are calling for the appellate structure based on individual BITs (Gantz, 2006, p. 39). Others suggests for the appellate structure to be attached to the ICSID system (Gleason, 2007, p. 287; Mann, 2011, p. 22 - 29). In addition there are those who suggests for the establishment of a single international appellate court for all investment disputes resembling to the WTO Appellate Body (UNCTAD, 2013, P. 3 - 4)). The proponents of the last suggestion base their argument on the successful story of the WTO Appellate Body.

Under the current ICSID investor - state adjudicative system the award rendered by the presiding Tribunal is not appealable save for few procedural remedies provided under the ICSID Convention (ICSID Convention, 1965, Art. 52(1)). The first remedy is to apply for supplementation and rectification (ICSID Convention, 1965, Art. 49(2)). This remedy empowers the Tribunal to correct minor omissions and technical mistakes only. The second remedy is for a party to seek interpretation of the award if there is an ambiguity on its meaning (ICSID Convention, 1965, Art. 50(1)). The objective of this remedy is to clear any misunderstanding on the meaning of the award (UNCTAD, 2003). The third remedy is to request for the revision of the award where there are new decisive facts which were unknown to the tribunal at the time of making its decision (ICSID Convention, 1965, Art.51 (1)). The fourth and major remedy is annulment of the award. This remedy is granted only where the party can prove either of the following: (1) that the tribunal was not properly constituted; or (2) the arbitral tribunal manifestly exceeded its powers; or (3) a tribunal member was corrupt; or (4) there was a serious departure from a fundamental rule of procedure; or (5) the award does not state the reasons upon which it was based (ICSID Convention, 1965, Art. 52(1)). Under the current system, decisions that are wrong as a matter of law are not reversible (ICSID Convention, 1965, Art.53). From these grounds it should be noted here that annulment does not involve evaluation of the correctness of the decision on merit rather it is more concern with the failure to observe the procedure.

For non ICSID awards, national legislations which are mostly based on the New York Convention and the UNCITRAL Model Law, also provides for a limited room of appeal against the award (UNCITRAL Model Law, 1985, Art. 34 \& 36)). The grounds includes: (1) the agreement to arbitrate was not valid, (2) the losing party was not given an opportunity to defend his case, (3) the award has addressed issues which are beyond its mandate, (4) the procedure employed did not comply with the parties' agreement, (5) the award has been set aside and is no longer binding, (6) the subject matter of arbitration is not subject to arbitration as per the laws of the place of enforcement and lastly (7) enforcement will be contrary to public policy (The New York Convention, 1958, Art. V). While the national court has a wider role in the Additional Facility awards and UNCITRAL Rules awards when compared to ICSID awards, the involvement is of insignificant effect as in most cases the court is not allowed to challenge the award on merit. This is due to the limitations set forth by the New York Convention (The New York Convention, 1958, Art. V).

The WTO Appellate Body on the other hand, has powers to hear appeal from panel reports on the point of law. That is to say the WTO AB has wider jurisdiction than the Annulment Committee and the National Courts hearing investor - state disputes (Dolzer \& Schreuer, 2008, P. 277). Appeal is distinct from annulment in the sense that the appellate court is concerned with the validity of the procedure involved in reaching at a particular decision and the correctness of the decision itself. In other words, appeal focuses on higher level of scrutiny to obtain greater accuracy in the legal reasoning (Yannaca - Small, 2010, p. 51). Annulment on the other hand is focused on correcting the procedural flaws committed in the course of reaching at a decision (Yannaca-Small, 2010, p. 51).

As discussed above, the Appellate Body is composed of seven permanent members who hear cases on circulation of three members per case (WTO DSU, 1995, Art. 17(1)). The tenure of the members is four years but they are eligible for a renewal of another single term. The law requires members to have expertise in law, international 
trade and the subject matter of the covered agreements generally (WTO DSU, 1995, Art. 17(3)). Distinct from the current investor - state Tribunals, adjudicating dispute at the WTO is meant to be a full time job for members hence they are required to be available on short notice and expected to acquaint themselves with the new development of the law and other activities of the WTO (WTO DSU, 1995, Art. 17(3)). The WTO therefore offers a good example of permanent based Appellate Body members. This is very important in the quest of increasing independence and impartiality of adjudicators. Currently the investor - state Tribunals are heavily controlled by the parties as the Tribunal is constituted by the parties themselves. Also the Tribunal members have no security of tenure as they depend on case by case basis appointment. The selection method and lack of tenure affects the legitimacy of the investor - state adjudicative system a great deal.

In addition, the appellate structure of the WTO has brought many advantages to the WTO DSU including predictability, consistency and a balanced dispute settlement system. As a result, the legitimacy of WTO DSU system is unshaken. The fact that all appeals are heard under one roof is another advantage which increases the chances of consistence and coherence of interpretation of the principles of the WTO Agreements.

Another advantage is that, through its jurisprudence the WTO has managed to balance the interests of both parties to the disputes hence increasing its legitimacy. This has been made possible due to the fact that the $\mathrm{AB}$ is presided by members who have expertise in public international law. Trade interests have been on a number of occasions been put on balance with other government policy objectives. For example, under Article XX of the GATT a range of government measures are considered valid if they are not arbitrary and unjustifiable and meant for protection of public morals; human, animals, or plant life or health; labor; cultural value and exhaustible natural resources. The WTO Appellate Body by recognizing the importance of other policy objectives has managed to create a stable jurisprudence on Article XX. In US V Gasoline case the US measure to regulate the composition and emission effects of gasoline in order to reduce air pollution was held valid despite the fact that it interfered with trade (WT/DS2/AB/R, 1996). Again, in European Communities-Measures Affecting Asbestos and Asbestos-Containing Products, the court decided to uphold French non trade objective (health) over Canada trade objectives. Also in Brazil - Retreaded Tyres the AB affirmed the relevancy of non - trade policies by holding that the import ban on retreaded tyres was apt to produce a material contribution to the achievement of its objective i.e. the reduction in waste tyre volumes (WT/DS332/AB/R, 2007). In summary, under the WTO non - trade policy objectives are given equal treatment.

\subsection{Possible Obstacles}

While it is true that the WTO successful story can act as an improvement motivation for investor - state adjudicative system, there are a number of issues which may hinder the system to achieve the legitimacy as that of the WTO. The major obstacle is the fragmented nature of the investor - state dispute settlement system. In the current system, an investor may commence an arbitration proceeding under a contractual arbitration clause providing for arbitration under the arbitral rules of the International Chambers of Commerce (ICC) or the UNCITRAL Arbitration Rules against a sovereign, (Kreindler, 2010 p.128) or decide to utilize the avenue available under the BIT and file a case with ICSID or ICSID Additional facility (Reinisch, 2010, p.113). In both scenarios the investor will have the right to do so as the rights have accrued from different instruments. Both avenues are independent from each other and have no appellate structure. With lack of a single coordinating institution, the like of DSB under WTO, the success story of WTO will do little to benefit the investor - state system. The WTO, as earlier on discussed, has a centralized dispute settlement bodies for all WTO Agreements.

It follows therefore that, for investor - state system to achieve this it will require the enactment of a multilateral treaty which provides for a centralized dispute settlement system. It is submitted here that despite the previous failures to establish the MAI the desire for a multilateral treaty is still there. In 2013 the World Economic Forum (WEF) through the Global Agenda Council on Global Trade and FDI issued a report calling for the global Multilateral Treaty for investments (World Economic Forum, 2013). The Report calls for the harmonization of the regulation of international investments. It is argued in the Report that the north - south divide that caused the failure of previous talks is withering away due to the fact that new economies has now became investors in the developed world (Draper,2013, p.23). The UNCTAD as well in 2013 issued a Paper suggesting introducing an appeals facility and creating a standing international investment court (UNCTAD, 2013). The voices for a multilateral investment system are in increase. Therefore, if these efforts results into a multilateral talks on harmonization of the regulation of international investment the possibility of establishing a body resembling to the WTO DSB and AB can be contemplated.

\section{Conclusion}

It can be said that the WTO has in a number of ways set up a good example to the investor - state adjudicative 
system on how to enhance legitimacy in the adjudicative system. First of all, the system has addressed the issue of litigation costs in the manner that allows poor countries equal access to the WTO DSU. The availability of the legal assistance Centre for developing countries is a very good initiative towards attaining a balanced adjudicative system. The DSB decision to carter for presiding members' costs in an appeal hearing is as well another excellent way of making the $\mathrm{AB}$ accessible whenever a party is not satisfied with the Panel decision. Secondly, the WTO DSU has effectively addressed the timeframe for settling disputes at different levels. The dispute is supposed to be resolved within 9 months if no appeal or 12 months where there is an appeal. Thirdly, the WTO DSU focus on rectification of the measure instead of punitive damages saves another good example of a legitimate adjudicative system. Lastly, the WTO AB working modality and functioning which balance both parties interests by recognising other policy objectives other than trade increases the legitimacy of the system as a whole. Therefore it can be said here that investor - state adjudicative system has a lot to learn from the WTO adjudicative system with regards to costs, timeframe, remedies and the appellate structure.

\section{References}

ACWL. (n. d.). Advisory Centre on WTO Law - About Us. Retrieved March 4, 2014, from http://www.acwl.ch/e/about/about-e.aspx

Bhala, R. (1999). The Myth About Stare Decisis and International Trade Law (Part One of a Trilogy). 14 American University International Law Review 845 at 856.

Bossche, P. (2005). The Law and Policy of the WTO: Text, Cases and Materials 172.

Department of Foreign Affairs and Trade of Australia. (2011). Trading our way to more jobs and prosperity. Retrieved January 25, 2013, from http://www.dfat.gov.au/publications/trade/trading-our-way-to-more-jobs-and-prosperity.html

Draft Bill on Promotion and Protection of Investment. (2013). Retrieved March 7, 2014, from http://www.tralac.org/files/2013/11/Promotion-and-protection-of-investment-bill-2013-Invitation-for-public -comment.pdf

Draper, P. et al. (2013). Towards Global Governance of FDI Issues on Getting to Multilateral Approach. In Foreign Direct Investment as a Key Driver for Trade, Prosperity and Growth: The Case for A Multilateral Agreement on Investment WEF 2013 p 29.

EU - Canada Comprehensive Economic and Trade Agreement (CETA). (n. d.). Retrieved November 11, 2014, from http://trade.ec.europa.eu/doclib/docs/2014/september/tradoc_152806.pdf

European Union Parliament. (2011). Report on the Future European International Investment Policy, A7-0070/2011 of 22 March 2011. Retrieved February 15, 2013, from http://www.europarl.europa.eu/sides/getDoc.do?pubRef=//EP//TEXT+REPORT+A7-2011-0070+0+DOC+ $\mathrm{XML}+\mathrm{V} 0 / / \mathrm{EN}$

Financial Times quoted in Investment Treaty News. (2014, May). Retrieved from http://www.iisd.org/sites/default/files/publications/iisd_itn_may_2014_en.pdf

Gaiger, R. (2011). Multilateral Approach to Investment. In J. Alvarez, \& K. P. Sauvant (Eds.), The Evolving International Investment Regime (pp. 153-173). http://dx.doi.org/10.1093/acprof:oso/9780199793624.003.0012

Howse, R. (2000). Adjudicative Legitimacy and Treaty Interpretation in International Trade Law: The Early Years of WTO Jurisprudence. In Weiler (Ed.), Towards a Common Law of International Trade? EU, WTO and NAFTA 211.

Hurst, R. (1971). Problem of Legitimacy in the Contemporary Legal Order. 24 Oklahoma Law Review 224.

International Centre for Settlement of Investment Disputes -ICSID). (2012). fees are set at US\$3000 a day see. Retrieved October 5, 2014, from https://icsid.worldbank.org/ICSID/FrontServlet?requestType=ICSIDDocRH\&actionVal=ShowDocument\& ScheduledFees $=$ True \&year $=2012$ \&language $=$ English

Lester, S. (2014, May). Improving Investment Treaties through General Exceptions Provisions: The Australian Example. Investment Treaty News. Retrieved May 16, 2014, from http://www.iisd.org/sites/default/files/publications/iisd_itn_may_2014_en.pdf 
Mann, H. (2011). Civil Society Perspective: what Do Key Stakeholders Expect from the International Investment Regime? In J. E. Alvarez, \& K. P. Sauvant (Eds.), The Evolving International Investment Regime: Expectations Realities, Options 22-29.

Nordstrom, H., \& Shaffer, G. (2014). Access to Justice in the WTO: A Case for a Small Claim Procedure. Retrieved March 26, 2014, from http://www.ruig-gian.org/ressources/Apea-NordstromShaffer_Small_Claims\%20070723.pdf

Nottage, H. (2009). Developing Countries in the WTO' GEG Working Papers 2009/47. Retrieved March 27, 2014 ,

from http://www.globaleconomicgovernance.org/sites/geg/files/Nottage_GEG\%20WP\%202009_47.pdf

Raviv, A. (2014). 'Achieving a Faster ICSID' 11 Transnational Dispute Management. Retrieved March 26, 2014, from http://www.transnational-dispute-management.com/article.asp?key=2066

Reinisch, A. (2009). The Future of Investment Arbitration. In Binder C. et al. (Eds.), International Investment Law for the 21st Century: Essays in Honour of Christoph Schreuer (pp. 894-916). http://dx.doi.org/10.1093/acprof:oso/9780199571345.003.0046

Report of the SRSG, Business and Human Rights: Further Steps Towards the Operationalization of the 'Protect, Respect and Remedy' Framework A/HRC/14/27, paras 20-23. (2010). Retrieved March 9, 2014, from http://www.ohchr.org/EN/Issues/Business/Pages/Reports.aspx

Schill, S. (2012). Deference in Investment Treaty Arbitration: Re-conceptualizing the Standard of Review through Comparative Public Law. SIEL Working Paper No 33/2012. Retrieved April 23, 2014, from http://papers.ssrn.com/sol3/papers.cfm?abstract_id=2095334

Schill, S. (2012). Deference in Investment Treaty Arbitration: Re-conceptualizing the Standard of Review through Comparative Public Law. SIEL Working Paper No 33/2012. Retrieved April 23, 2014, from http://papers.ssrn.com/sol3/papers.cfm?abstract_id=2095334

Speech delivered by the Minister of Trade and Industry of South Africa. (2012). Dr Rob Davies at the South African launch of the United Nations Conference on Trade and Development (UNCTAD) Investment Policy Framework for sustainable development at the University of The Witwatersrand on $26^{\text {th }}$ July 2012. Retrieved March 7, 2013, from http://www.info.gov.za/speech/DynamicAction?pageid=461\&sid=29391\&tid=77861

Sutherland, P. et al. (2004). The Future of the WTO: addressing institutional challenges in the new millennium. WTO Consultative Board. Retrieved March 26, 2014, from http://www.wto.org/english/thewto_e/10anniv_e/future_wto_e.pdf

The Department of Trade and Industry. (2009). Republic of South Africa's Government Position Paper on Bilateral Investment Treaty Policy Framework Review. Retrieved February 7, 2013, from http://www.thedti.gov.za/ads/bi-lateral_policy.pdf

The Office of the United States Trade Representative. (2014). US Model Bilateral Investment Treaty (2012), Art.12. Retrieved February 23, from http://www.ustr.gov/assets/Trade_Sectors/Investment/Model_BIT/asset_upload_file847_6897.pdf

The Report of the SRSG. (2009). Business and Human Rights: Towards Operationalizing the 'Protect, Respect and Remedy' Framework A/HRC/11/13, para 30.

Torres, R. A. (2012, February). Use of the WTO Trade Dispute Settlement Mechanism by the Latin American Countries - Dispelling Myths and Breaking Down Barriers. prepared by the WTO - Economic Research and Statistic Division. Retrieved March 25, 2014, from http://www.wto.org/english/res_e/reser_e/ersd201203_e.htm

UNCTAD. (2010). Investor - State Dispute: Prevention and Alternative to Arbitration. Retrieved October 5, 2013, from http://www.unctad.org/en/docs/diaeia200911_en.pdf

UNCTAD. (2013). Reform of Investor-State Dispute Settlement: In Search of a Roadmap. IIA Issue Note No. 2. Retrieved March 4, 2014, from http://unctad.org/en/PublicationsLibrary/webdiaepcb2013d4_en.pdf

United Nations Conference on Trade and Development (UNCTAD). (2012). Towards a New Generation of Investment Policies. World Investment Report at p 84 Retrieved February 21, 2013, from http://unctad.org/en/PublicationsLibrary/wir2012_embargoed_en.pdf 
US Model Bilateral Investment Treaty. (2012). Retrieved February 23, 2013, from http://www.ustr.gov/assets/Trade_Sectors/Investment/Model_BIT/asset_upload_file847_6897.pdf

Vadi, V., \& Gruszczynski, L. (2013). Standards of Review in International Investment L aw and Arbitration: Multilevel Governance and the Commonweal. Journal of International Economic Law, 16(3), 613-633. http://dx.doi.org/10.1093/jiel/jgt022

Van Harten, G. (2010). Investment Treaty Arbitration, Procedural Fairness and the Rule of Law. In Schill, S. (Ed.), International Investment Law and Comparative Public Law (pp. 627-658). http://dx.doi.org/10.1093/acprof:oso/9780199589104.003.0020

Van Harten, G. et al. (2010). Public Statement on the International Investment Regime. Retrieved January 23, 2013, from http://tinyurl.com/3qhnjwr

World Economic Forum. (2013). The Global Agenda Council on Global Trade and FDI. Foreign Direct Investment as a Key Driver for Trade, Prosperity and Growth: The Case for A Multilateral Agreement on Investment. $\quad$ Retrieved February $\quad 18, \quad$ 2014, from http://www3.weforum.org/docs/GAC13/WEF_GAC_GlobalTradeFDI_FDIKeyDriver_Report_2013.pdf

WTO Official Website. (2014). Retrieved March 26, 2014, from http://www.wto.org/english/tratop_e/dispu_e/dispu_status_e.htm

Zimmermann, T. (2005). WTO Dispute Settlement at Ten: Evolution, Experiences and Evaluation. 60 The Swiss Review of International Economic Relations 27.

\section{Cases}

Aguas del Tunari S A v Bolivia ICSID ARB/02/3 (2005).

Azurix Corp v Argentina ICSID ARB/1/12 (2006).

CMS Gas Transmission Company $v$ The Argentine Republic ICSID ARB/01/8(2005).

EC Measures Concerning Meat and Meat Products, WT/DS26/AB/R, WT/DS48/AB/R, (1998).

Enron Corporation and Ponderosa Assets L P v Argentine Republic ICSID ARB/01/3 (2007).

Lauder v The Czech Republic, 9 ICSID Reports 66 and CME Czech Republic BV v The Czech Republic 9 ICSID Reports 121 (2003).

Philip Morris Asia Limited v The Commonwealth of Australia, UNCITRAL, PCA Case No. 2012-12.

SGS Société Générale de Surveillance S A v Islamic Republic of Pakistan ICSID ARB/01/13 (2004).

SGS Société Générale de Surveillance S A v Republic of the Philippines, ICSID ARB/02/6 (2005).

Vattenfall v Federal Republic of Germany, ICSID Case No. ARB/12/12 (2012).

\section{Copyrights}

Copyright for this article is retained by the author(s), with first publication rights granted to the journal.

This is an open-access article distributed under the terms and conditions of the Creative Commons Attribution license (http://creativecommons.org/licenses/by/3.0/). 